\title{
Distribution Patterns and Biological Characteristics of Aristeus Antennatus (Risso, 1816) and Aristeus Virilis (Bate, 1881 ) in Mozambique Waters of the Western Indian Ocean
}

\author{
Ignacio Sobrino', Nilza Dias ${ }^{3}$ Isabel Muñoz', Francisca Salmerón ${ }^{2}$ and Dionisio Varela ${ }^{3}$ \\ ${ }^{1}$ Instituto Español de Oceanografía Unidad de Cádiz, Muelle Pesquero s/n Apdo: 290611006 Cádiz Spain; \\ ${ }^{2}$ Instituto Español de Oceanografía. Centro Oceanográfico de Málaga. Apdo: 28529640 - Fuengirola \\ (Málaga), Spain: ${ }^{3}$ Instituto de Investigaçao Pesqueira. Avda Mao Tse Tung Maputo Mozambique
}

\begin{abstract}
Keywords: Aristeus antennatus; Aristeus virilis; distribution, biology, deep water shrimp, Mozambique.
\end{abstract}

\begin{abstract}
The blue and red shrimp, Aristeus antennatus (Risso, 1816), and the stout red shrimp, Aristeus virilis (Bate, 1881), represent two of the most valuable demersal deep waters shrimp species subject to exploitation in Mozambique. This paper analyses the distribution, abundance and biological parameters of these species for the first time in this area. During 13th March to 10th April a survey on board the R/V Vizconde de Eza has been carried out to assess deep water crustacean resources in Mozambique waters. The sampling design followed a random stratified scheme with five sectors (Sofala, Bazaruto A, Bazaruto B, Boa Paz and Inhaca) and also five depth strata (A: $100-200$ m, B: 200-400 m, C: 400-500 m, D: 500-600 m, E: 600-700 m).

For the overall area surveyed, A. virilis was twice more abundant than A. antennatus (95.44 tons and 37 tons respectively) and more abundant in central and south area (Bazaruto B; Boa Paz and Inhaca), while A. antennatus was more abundant in the north area (Sofala). Both species live in deep water and were caught between 420 to $675 \mathrm{~m}$ and 520 to $690 \mathrm{~m}$, for A. antennatus and $A$. virilis respectively. Size of first maturity occurred at of $19.8 \mathrm{~mm}$ and $25.5 \mathrm{~mm}$ of cephalotorax length (CL) for males of A. antennatus and A. virilis respectively, and $34.7 \mathrm{~mm}$ and $47.5 \mathrm{~mm}$ of CL for females of A. antennatus and A. virilis, respectively.
\end{abstract}

\section{INTRODUCTION}

The fisheries sector in Mozambique is an important source of economic earning, animal protein and employment. Total marine products are estimated at between 100,000 to 120,000 tonnes per year and consumption is estimated at $7.5 \mathrm{~kg}$ per capita. The fisheries industries provide direct employment for around 90,000 people, excluding those involved in trading and processing (Afonso, 2006).

The industrial fishery using bottom trawl is responsible for deep water shrimp catches. Deep water shrimps contribute with about $7 \%$ of the total value of industrial fisheries; between 2001 and 2003 deep shrimp fisheries realised about 1,500 tonnes with a $7,125,000$ US $\$$ value. This subsector consists of joint ventures between the Government of Mozambique and foreign companies form Japan and Spain and Portugal. They have sufficient financial resources to enable them to support a modern fleet, and export their products to the international markets in which they are well established, such as Spain and Japan (FAO, 2004). The fleets of these companies have the major part of the quotas - more than $70 \%$ of the Total Allowable Catch (TAC). The major products include shallow- and deep-water shrimps, lobster, 
fish and some tuna, most of which are for export markets. In 2001, exports reached US\$ 100 million, representing over $40 \%$ of the country's earnings. Frozen directly on trawlers, shrimps are exported mainly to Japan, South Africa and the European Union. According to recent assessments carried out by Dias and Caramelo (2007), the main deep water shrimp fisheries are currently under-exploited.

Deep water shrimps occur in Mozambique waters from $18^{\circ} 00^{\prime} \mathrm{S}$ to $26^{\circ} 50^{\prime} \mathrm{S}$. In the northern part, trawling is difficult due to the existence of canyons and coral reefs and it is not possible to survey this area.

The main deep water shrimp resource is comprised chiefly of the following species: Haliporoides triarthrus vniroi (Stebbing, 1914) and Aristaemorpha foliacea (Risso, 1827), and secondary are Aristeus antennatus (Risso 1816) and Aristeus virilis (Bate, 1881) (FAO, 2006). Management measures include TACs, mesh size limits and vessel licensing requirements.

In the western Mediterranean Sea, the blue and red shrimp, A. antennatus, is one of the most valuable demersal species exploited. Although growth parameters, reproductive aspect and population dynamics of $A$. antennatus have been widely investigated in different areas of the Mediterranean Sea (Sardá \& Demestre 1987, Demestre 1995; Demestre \& Lleonart 1993, Demestre \& Martín 1993, Martínez-Baños 1997, Carbonell et al. 1999, García-Rodríguez \& Esteban 1999a,b,. Sardá et al. 2001), in the Indian Ocean only its presence is described (Holthius, 1980), while biological information is very scarce. The stout red shrimp A. virilis has a wide distribution in the Indian Ocean but biological information about this species is also very scarce (Pérez-Farfante and Kensley 1997).

The present work aims to contribute to the knowledge of two Aristeus species, A. antennatus and $A$. virilis, in Mozambique waters using data obtained during a scientific survey carried out under a cooperation programme between the government of Spain and Republic of Mozambique.

\section{MATERIALS AND METHODS}

\section{Sampling}

The data used in the study comes from a survey whose main purpose was to assess the deep water crustacean resources in Mozambique's EEZ, between latitudes $17^{\circ} 00^{\prime}$ and $26^{\circ} 50^{\prime} \mathrm{S}$, from 100 to $700 \mathrm{~m}$ depth. This survey (Mozambique 0307) was carried out using the R/V Vizconde de Eza from $13^{\text {th }}$ March to $10^{\text {th }}$ April 2007, using an otter trawl as sampling gear. A random stratified sampling design was applied, taking into account five geographical sectors (Sofala Bank, Bazaruto A, Bazaruto B, Boa Paz and Inhaca) and five bathymetric strata (A: $100-199$ m; B: $200-399$ m; C: $400-499$ m; D: 500-599 m; E: 600-700 m) (Figure 1). A total of 129 fishing stations of $30 \mathrm{~min}$ duration and a speed of 3 knots were sampled. An estimation of the biomass was made using the swept area method (Sparre and Venema, 1992)

The trawling speed and geographic position were measured using differential GPS, and the trawl geometry and performance were observed using a SIMRAD ITI remote sensor system. All fishing operations were carried out during daylight hours (07:00-19:00h).

\section{Carapace Length and body weight}

From each haul, catch was sorted by species, counted and weighed. The individuals were sexed and measured by their cephalotorax length (CL in $\mathrm{mm}$ ), taken from the posterior part of the left orbit to the centre of the posterior edge of the carapace, to the nearest millimetre. Total catch was weighed and individual specimens weighed to the nearest $0.1 \mathrm{~g}$. Significant deviations from the $1: 1$ sex-ratio were tested by the $\chi 2$-test $(\mathrm{P}<0.05)$.

\section{Aspects of reproduction}

Others biological data were also recorded, notably sex, presence of spermatophore on the thelycum and gonad maturity stage of females. A four-stage maturity scale based on the macroscopic observation of the gonad (size and colouring) was applied to females, according to Sobrino (1998): 1: virgin, 


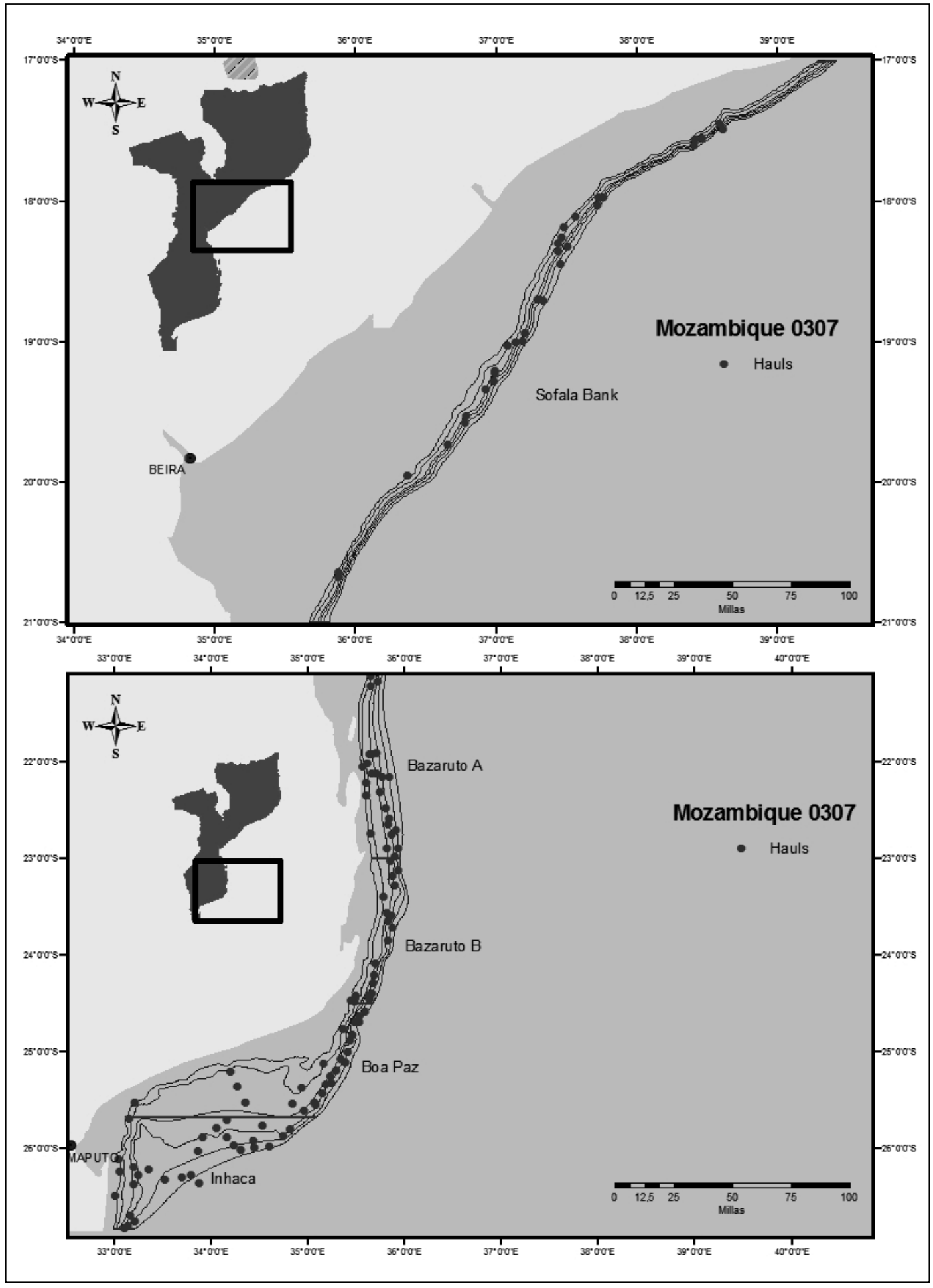

Fig. 1. Study area in Mozambique waters. Dot symbols indicate locations of hauls 
2: developing, 3: pre-spawning and 4: spawning, considering stages 1 and 2 as immature and 3 and 4 as mature. For males, a two-stage maturity scale was applied (immature and mature) based on the presence or absence of spermatic mass in the coxae of the fifth pair of pleiopods. The formation of the petasma (separate or joint) was moreover followed as a secondary sexual characteristic (Demestre, 1990). The moulting activity was also considered and the specimens in moulting process or with soft body were recorded.

The size at maturity $\left(\mathrm{CL}_{\mathrm{m} 50 \%}\right)$ was estimated after fitting, by the least squares method, the relative length frequency distribution of mature individuals to a logistic curve from the expression: $\mathrm{P}_{\mathrm{i}}=1 /$ $\left(1+\exp \left(a+b C L_{i}\right)\right)$, where $P_{i}$ represents the relative frequencies of fully mature individuals in lengthclass $\mathrm{CL}_{\mathrm{i}}$, a and $\mathrm{b}$ are the regression constants, and $\mathrm{CL}_{\mathrm{m} 50 \%}=-\mathrm{a} / \mathrm{b}$ (see Sparre and Venema, 1992).

\section{RESULTS}

\section{Distribution pattern and abundance}

In Mozambique waters $A$. virilis is more abundant than A. antennatus. Total biomass for $A$. virilis was of 95.44 tonnes and 37 tonnes for A. antennatus ( $72 \%$ and $38 \%$ respectively). Both species were more abundant in the north area (Banco de Sofala) and in the south area (Inhaca). In the case of $A$. antennatus this species was inexistent in Boa $\mathrm{Paz}$ and Bazaruto B (Figure 2a).

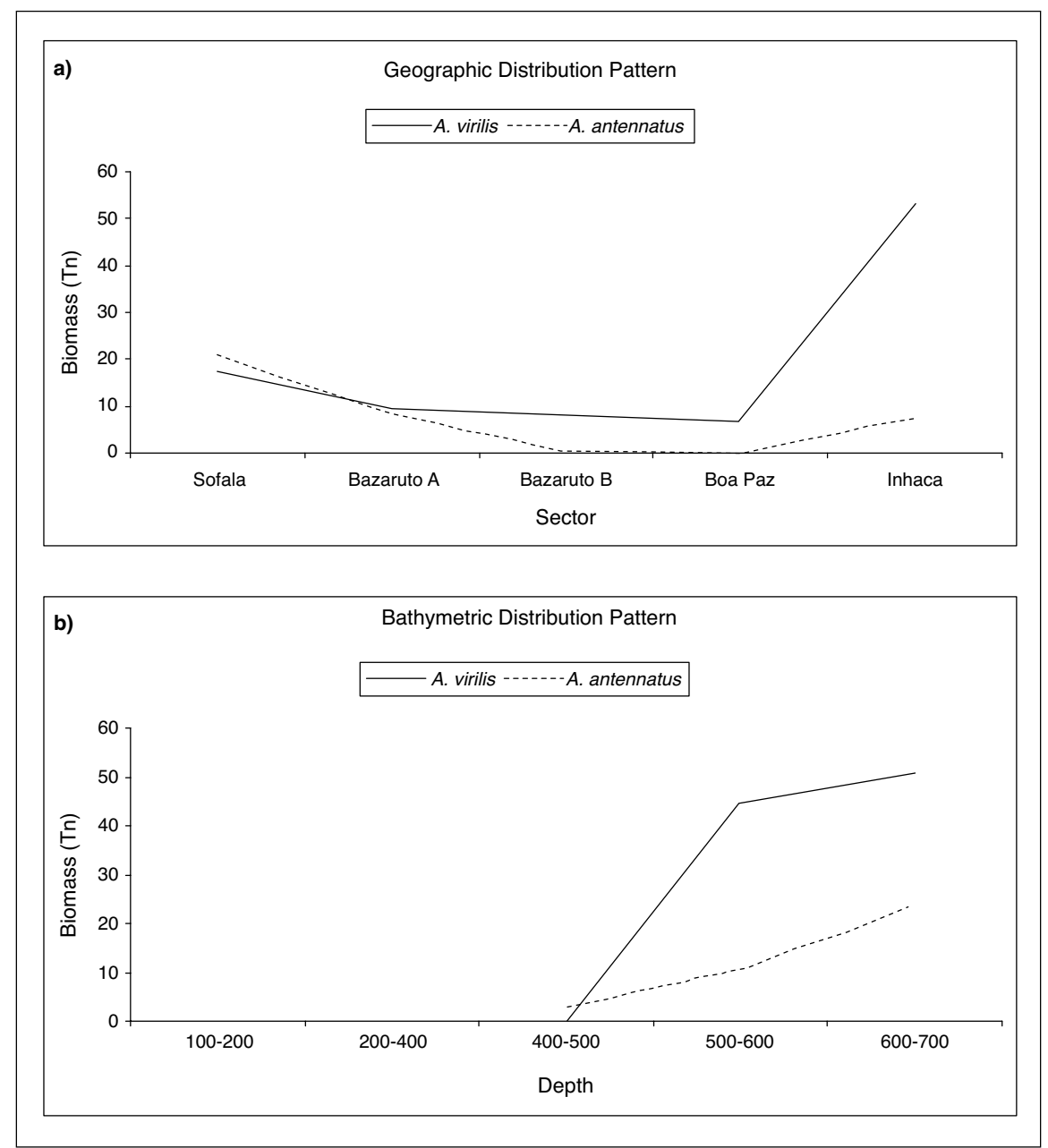

Fig. 2. Abundances of both species by geographic sector (a) and depth (b) 
With respect to water depth, theses species were caught between 531 to $674 \mathrm{~m}$ and 456 to $679 \mathrm{~m}$ for A. virilis and A. antennatus respectively. The higher abundances were recorded between 600 to $700 \mathrm{~m}$ for both species (Figure 2b). For A. virilis a similar yield was obtained in the last two deeper strata, while for A.antennatus in 600 to $700 \mathrm{~m}$ depth the biomass was higher than in the 500 to $600 \mathrm{~m}$ range.

\section{Size frequency distribution and sex ratio}

The size range for A. virilis was 20 to $73 \mathrm{~mm}$ of CL with a mean value of 31.4 and $39.1 \mathrm{~mm} \mathrm{CL}$ for males and females respectively (see Figure 3), where a single mode for both sexes was observed. In the case of $A$. antennatus, the size range was between 14 to $64 \mathrm{~mm}$ of CL. Mean CL for males was $25.6 \mathrm{~mm}$ and for females $35.7 \mathrm{~mm}$ CL. For

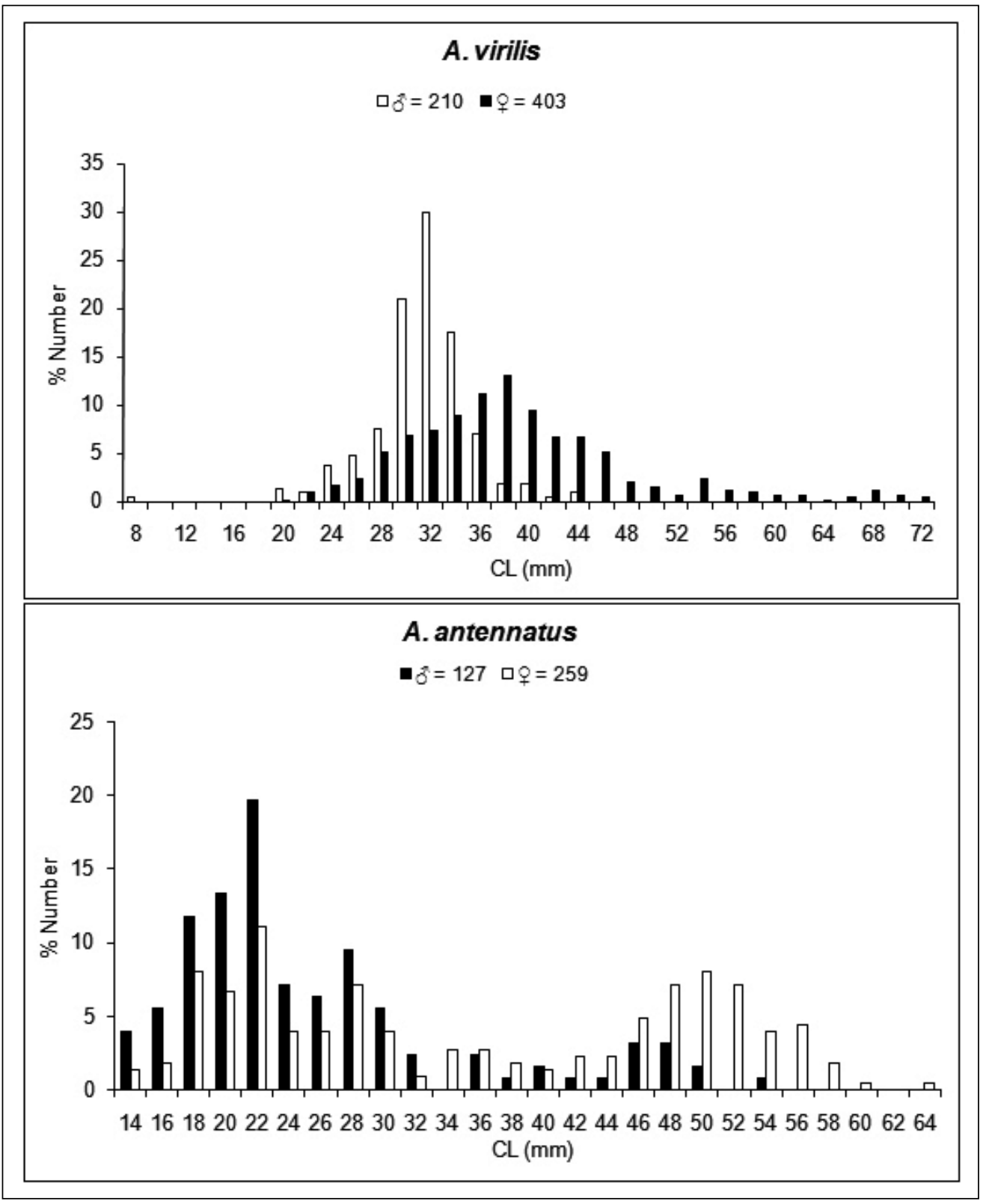

Fig. 3. Percentage by sex of size-class in the total studied area 
this species two different modes were noted: one between 14 to $34 \mathrm{~mm}$ (medium size) and other of 42 to $62 \mathrm{~mm}$ (large size). All large specimens were concentrated in the north area (Sofala). Also for $A$. antennatus females are larger than males, with a mean CL of $25.6 \mathrm{~mm}$ and $35.7 \mathrm{~mm}$ for males and females, respectively.

When the mean size by depth is analysed (see Figure 4), there is no difference in the case of $A$. virilis and the mean size by depth stratum are similar in each sex, but for A. antennatus mean size increases with depth until 500-600 m, decreasing afterwards for both sexes.

The overall sex ratio for both species was significantly in favour of females $(65.7 \%$ for A. virilis and $71.8 \%$ for A. antennatus). It was observed that at small and medium sizes, the sex ratio was nearly $50 \%$, but at the large size the sex ratio was significantly in favour of females for both species (see Figure 5).
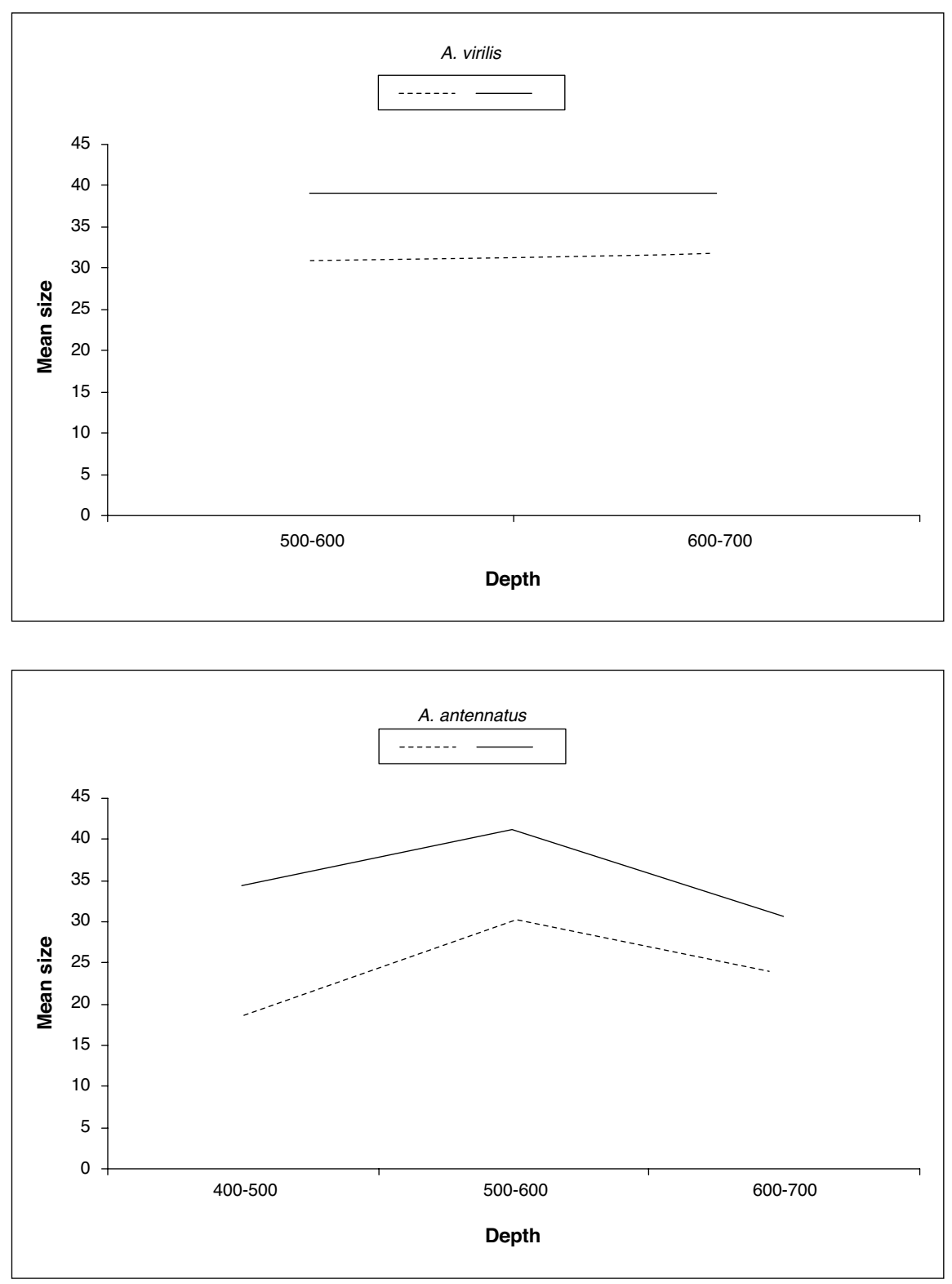

Fig. 4. Mean size by depth for A. virilis (a) and A. antennatus (b) 


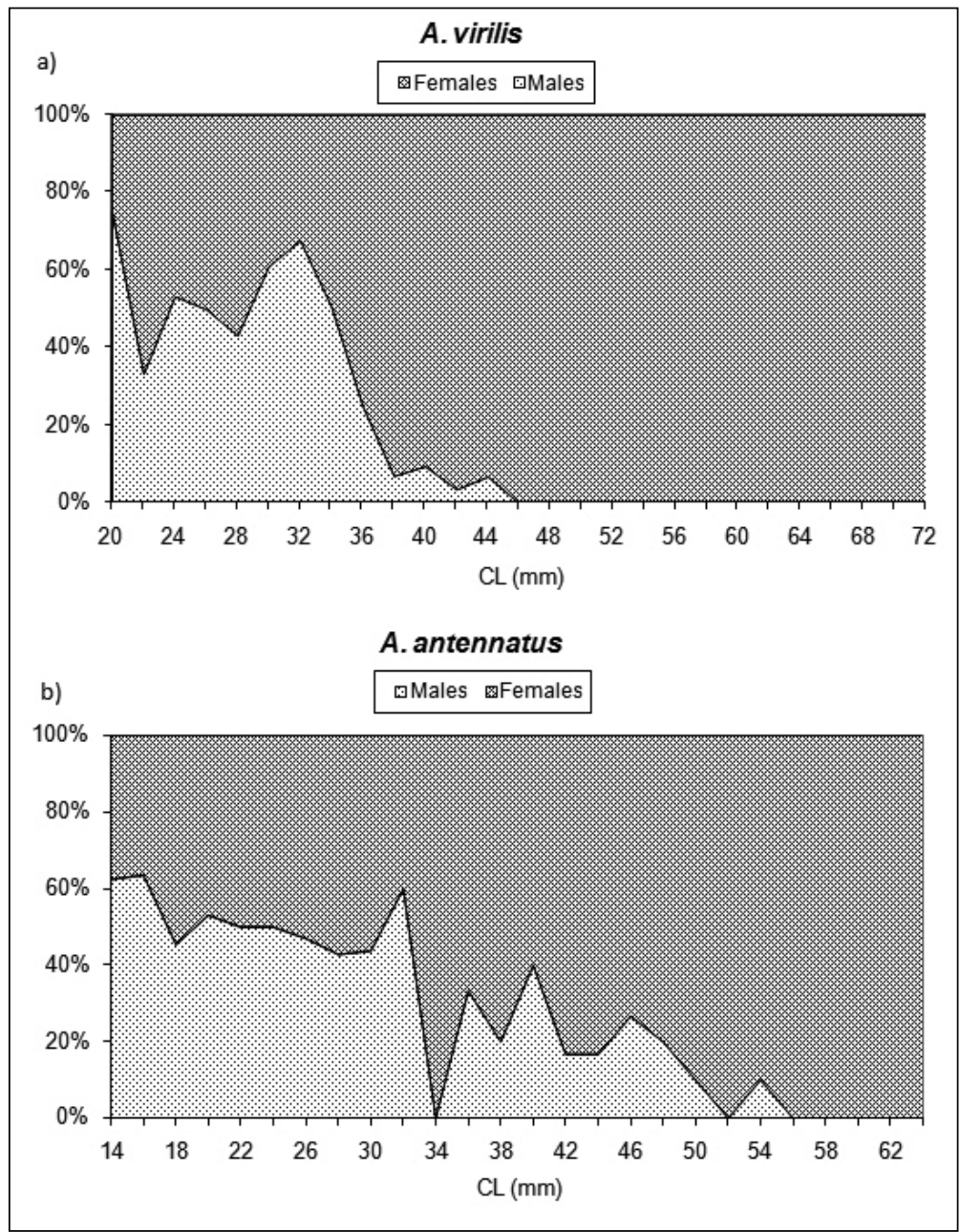

Fig. 5. Sex-Ratio by length for both species (A. virilis (a) and A. antennatus (b))

\section{Reproductive aspects}

For A. virilis females only $12.5 \%$ of specimens were mature but $47.3 \%$ of females were carrying spermatophore in their thelycum. All mature females were impregnated. The smallest mature impregnated female $A$. virilis measured $27.8 \mathrm{~mm}$ $\mathrm{CL}$ and the smallest immature impregnated female was $20.13 \mathrm{~mm}$ CL. Regarding depth distribution, as seen in Figure 6, it is observed that the majority of mature females were caught between 550-575 $m$ depth. These results show that the period of survey did not coincide with the spawning time, reflected in the calculated maturity size data for females not fitting well to the model $\left(r^{2}=0.69\right)$, as shown in Figure 7. For males, maturity size was calculated at between $25.5 \mathrm{~mm}$ CL (\% spermatic mass in coxae) and $27.0 \mathrm{~mm} \mathrm{CL}$ (\% petasma joint) (see Figure 7).

With regard to A. antennatus $31.65 \%$ of specimens were mature and $34.3 \%$ of females were carrying spermatophore in their thelycum. The majority of mature females were impregnated. The smallest impregnated mature A. antennatus measured $18.4 \mathrm{~mm} \mathrm{CL}$ and the smallest immature impregnated female was $18.7 \mathrm{~mm}$ CL.

Regarding water depth, (Figure 6) the majority of mature females were founded between 550-575 $\mathrm{m}$ and $675 \mathrm{~m}$ depths. These results show that the period of survey was close to the spawning time. The calculated maturity size was found to correlate well $\left(r^{2}=0.74\right)$ as seen in Figure 8. The calculated 


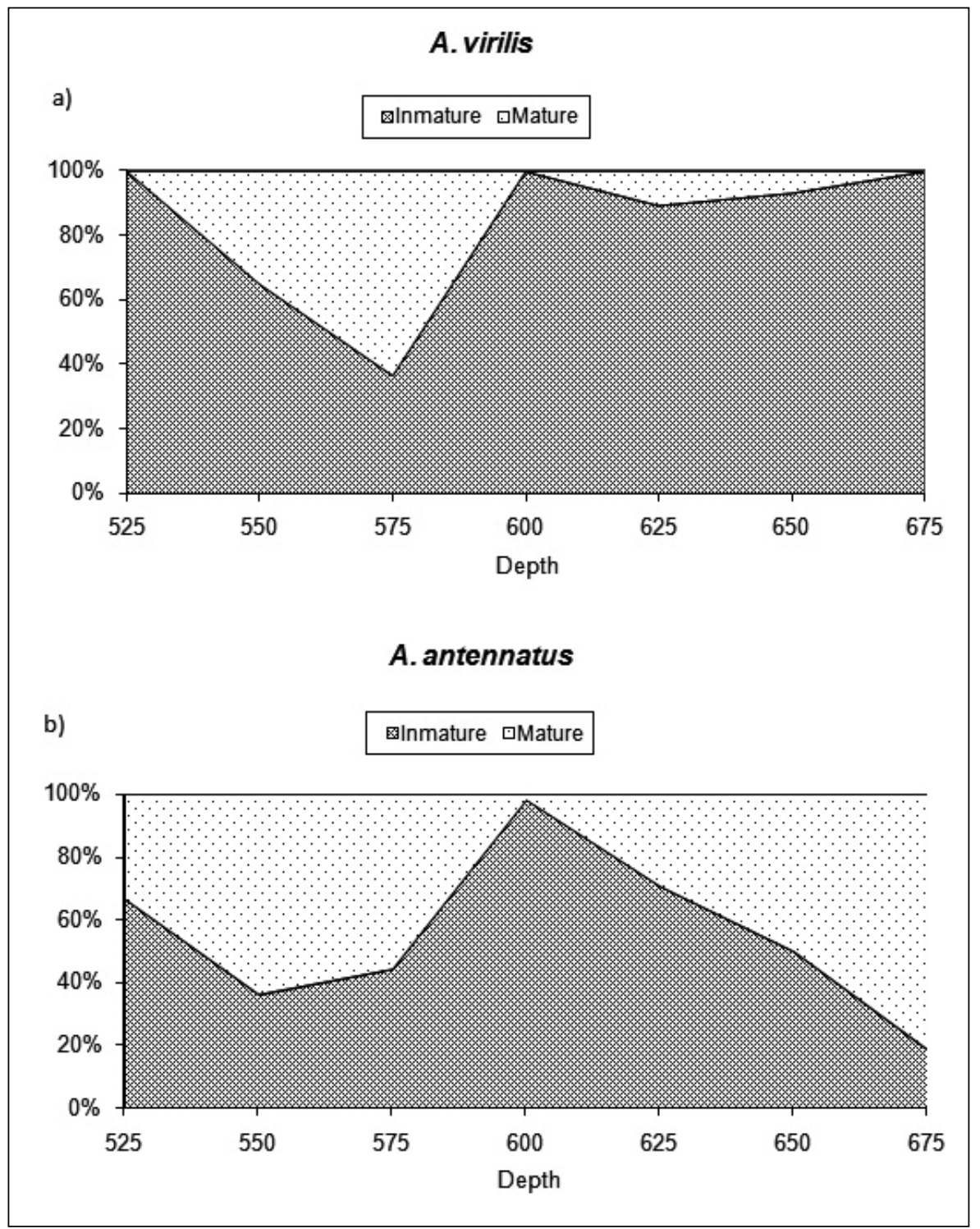

Fig. 6. Percentage mature females by depth (A. virilis (a) and A. antennatus (b))

size of maturity was $34.7 \mathrm{~mm}$ CL (\% mature stage) and $37.0 \mathrm{~mm}$ CL when the \% of impregnated females was used. For males, the calculated size at maturity varied between $19.8 \mathrm{~mm} \mathrm{CL}(\%$ spermatic mass in coxae) and $22.3 \mathrm{~mm} \mathrm{CL}$ (\% petasma joint) (Figure 8).

Moulting activity was very limited in both species during the study period. Only six of 397 specimens of $A$. antennatus and 21 of 469 of $A$. virilis were soft-shelled.

\section{DISCUSSION}

Both species constitute part of the resource exploited by the trawling fleet targeting deep water shrimp resources, of high economic value.

Even though there is no precise catch information for these two species in Mozambique waters, the results obtained during this survey indicate that these two species constitute $3 \%$ of the total crustaceans of commercial interest. Among the deep water shrimp species are also included the knife 

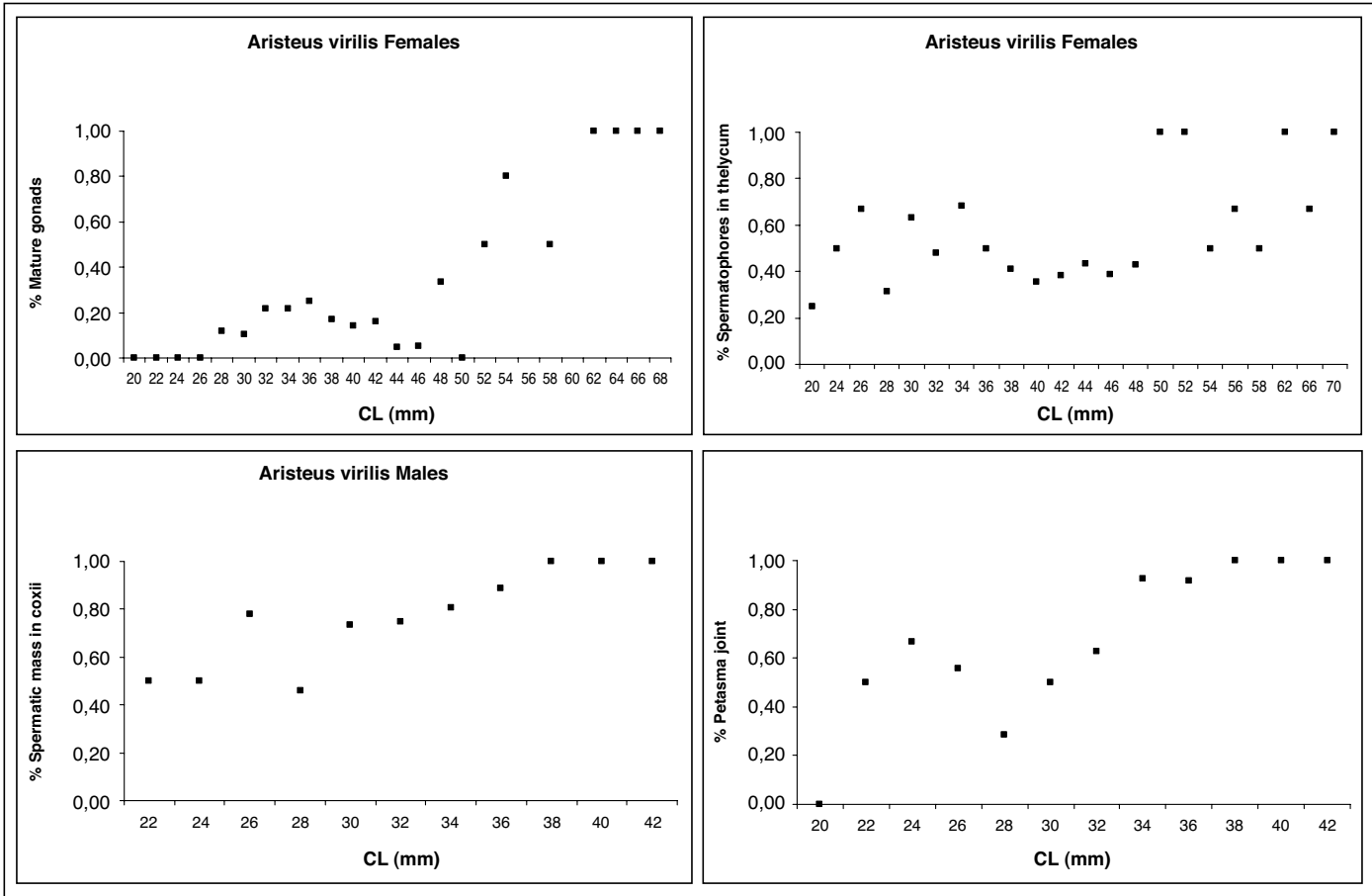

Fig. 7. Maturity at length ogive by sex for $A$. virilis, for females with mature gonads (top left), fecund females with spermatophores in thelycum (top right); males with spermaceti mass in coxii (bottom left) and males with petasma joints (bottom right)
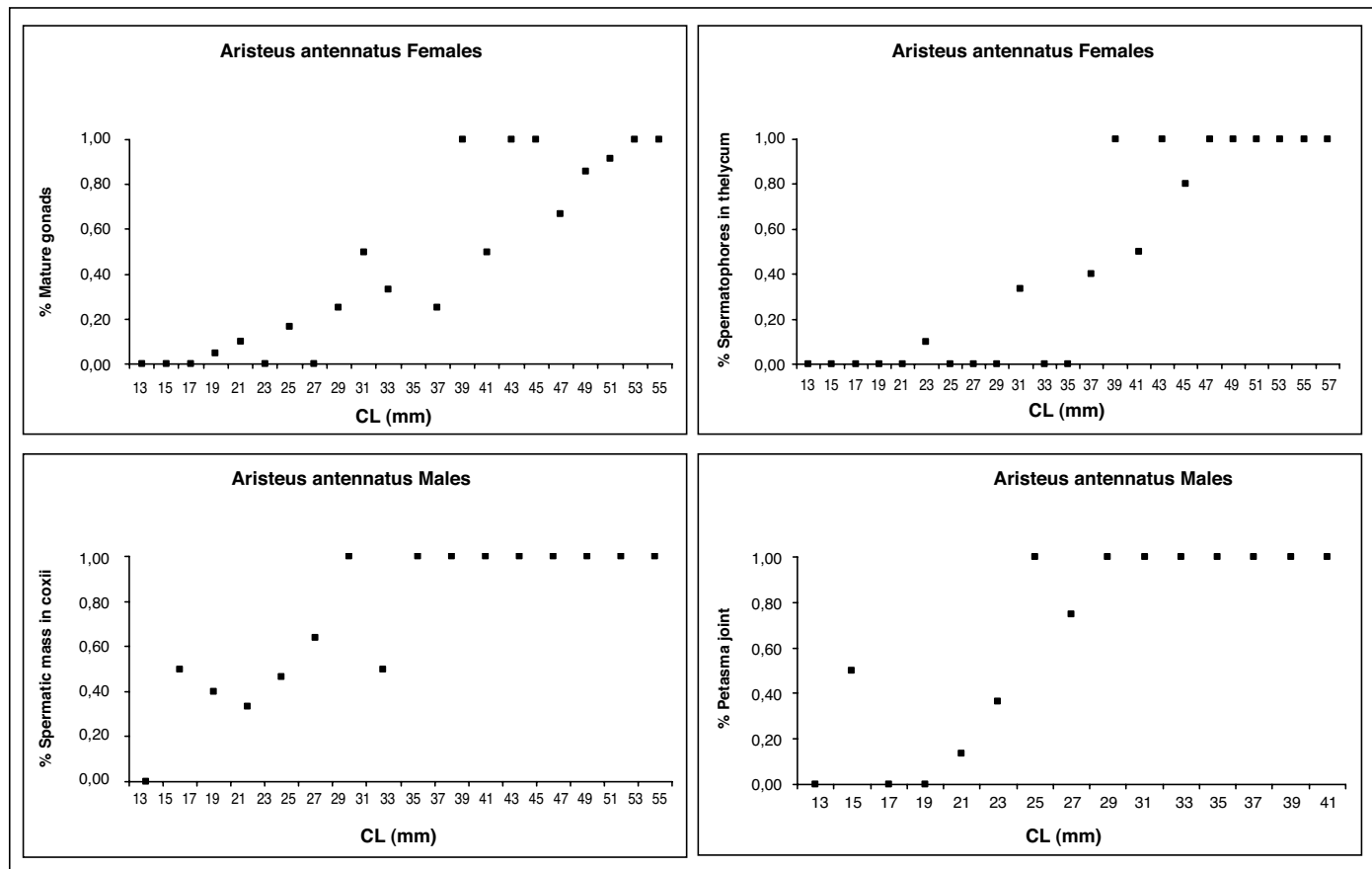

Fig. 8. Maturity at length ogive by sex for A. antennatus, for females with mature gonads (top left), fecund females with spermatophores in thelycum (top right); males with spermaceti mass in coxii (bottom left) and males with petasma joints (bottom right) 
shrimp (Haliporoides triarthrus, Stebbing, 1914); Giant red shrimp (Aristaeomorpha foliacea. Risso, 1827); Scarlet shrimp (Aristaeopsis edwardsiana . Johnson, 1863) and Needle shrimp (Penaeopsis balssi. Ivanov and Hassan 1976). Similar results were previously found by Fennessy and Groeneveld (1997) in Indian Ocean waters of South Africa's coast.

In spite of some differences in distribution patterns, the two Aristeus species were found along all surveyed areas. A. antennatus was more abundant between 550 and $650 \mathrm{~m}$, while A. virilis abundance increases with the depth having a maximum valour in the range of 600-700 m.

However, there is an indication that the depth limit of $700 \mathrm{~m}$ would not be the limit of the vertical distribution of the two species. Also observed was a distinct geographical preference along the coast for the two species, with A. antennatus virtually absent from the central areas surveyed.

In Mediterranean waters, where the fishery for thess species is predominant, the sames species occurs in a bathymetric range from 400 to $3,300 \mathrm{~m}$ depth (Sardá et al., 2004), with highest abundance between 400 and $800 \mathrm{~m}$ depth. According to Sardá and Demestre (1987), the main fishery occurrs over grounds between 400 and 1,000 m depth. In Portugal, according to Ribeiro-Cascalho and Arrobas (1982) these species occur between 350 and $650 \mathrm{~m}$ depth. The latter depth ranges are in accordance with the deep water shrimp fishery in Mozambique, which does not occur deeper than 700 $m$ of depth (Dias and Caramelo 2007). Similarly, in South Africa there is a fishery between 300 and $600 \mathrm{~m}$ (Fenessy and Groeneveld, 1997). However, it has to be taken in consideration that the fisheries in the latter two countries mentioned have as the main target $H$. thriarthrus, whose bathyimetric distribution range is restricted to $700 \mathrm{~m}$ depth ( Muñoz et al., 2007).

The distinction on both species in terms of depth and latitude were mainly due to the absence of $A$. antennatus in such areas as Bazaruto A, Bazaruto B and Boa Paz. In $95 \%$ of the trawling samples where A. antennatus were caught, it occurred with A. virilis. However, $48.5 \%$ of the trawling samples where $A$. virilis was caught were not accompanied by A. antennatus.
The population structure of $A$. antennatus was similar to results from other surveys. In diverse studies in western Mediterranean waters it is shown a cephalothorax length range between 18 and $42 \mathrm{~mm}$ for males and 15 to $61 \mathrm{~mm}$ for females (Demestre 1990). In Atlantic waters of southern Portugal, males were reported with similar values $(19-40 \mathrm{~mm}$ ) and 17-68 $\mathrm{mm}$ for females (Arrobas andRibeiro-Cascalho, 1987). Meanwhile in this survey, the males present a maximum carapace length at $54 \mathrm{~mm}$. The sex ration pattern found in other studies (Arrobas and Ribeiro-Cascalho, 1987; Demestre, 1990) where similar to the findings of the present study.

The lack of previous reproductive studies of $A$. virilis does not allow comparison with other regions, therefore the values obtained can be considered as a first approximation, mainly because there were not sampled during the reproduction peak season. On the other hand, a higher percentage of $A$. antennatus females were found, which can suggest that they were close to a reproduction peak season, therefore the results show a better adjustment to the calculated length at maturity. These results are also considered the first estimates in Mozambique waters. From diverse studies performed with this species in Mediterranean waters (Demestre, 1990; Martínez Baños and Mas, 1994; Carbonell, 1994; García-Rodríguez, 2003), calculated maturity lengths given are about 17 to $22 \mathrm{~mm}$ CL for males, close to the results obtained in the present study, and 22 to $27 \mathrm{~mm} \mathrm{CL}$ for females, lower than the present results.

Acknowledgments - The authors are grateful to the crew of V/O Vizconde de Eza for his work and proficiency, as well as to the rest of colleagues of the Instituto Español de Oceanografía and the Instituto de Investigaçao Pesqueira of Mozambique that participated in the survey.

\section{BIBLIOGRAPHY}

Afonso, P.S. (2006) Country review: Mozambique.In: De Young, C. (ed.). Review of the state of world marine capture fisheries management: Indian Ocean. FAO Fisheries Technical Papers - T488 ISBN: 9251054991.

Arrobas, I., and Ribeiro-Cascalho, A. (1987). On the biology of Aristeus antennatus (Risso, 1816) in the 
south Portugueses coast. Inv. Pesq., 51(Supl.1), 233-243.

Carbonell,A. (1994). Life cycle of Aristeus antennatus on Majorca Island waters. Proceedings of International Workshop "Life cycles and fisheries of the deep-water red shrimps Aristaeomorpha foliacea and Aristeus antennaturs" Mazzara del Vallo, M.L. Bianchini and S. Ragonese (Eds.), N.T.R.-I.T.P.P., Special Publication 3, 13-14.

Carbonell, A., Carbonell, M., Demestre, M., Grau, A., and Monserrat, S. (1999) The red shrimp Aristeus antennatus (Risso, 1816) fishery and biology in the Balearic Islands, western Mediterranean. Fish Res 44, 1-13

Demestre, M. (1990). Biologia pesquera de la gamba Aristeus antennatus (Risso, 1816) en el Mar Catalán. Ph. D. Thesis doctoral, Universidad Barcelona

Demestre, M. (1995) Moult activity-related spawnig success in the Mediterranean deep-water shrimp Aristeus antennatus (Decapoda: Dendrobranchiata). Mar Ecol Prog Ser 127, 57-64

Demestre, M., and Lleonart, J. (1993) Population dynamics of Aristeus antennatus (Decapoda: Dendrobranchiata) in the northwestern Mediterranean. Sci Mar 57, 183-189

Demestre, M., and Martín, P. (1993) Optimum exploitation of a demersal resoruce in the western Mediterranean: the fishery of the deep-water shrimp Aristeus antennatus (Risso, 1816). Sci Mar 57, 175-182

Dias, N., and Caramelo, A. M. (2007). Avaliação do estado dos stocks de gambas em Moçambique. Revista de Investigação Pesqueira 26.

FAO (2004). Fishery Country Profile- The Republic of Mozambique (April 2004). FID/CP/MOZ.

FAO (2006). South West Indian Ocean Fisheries Commission. FAO Fisheries Report. No. 806. Rome, FAO.

Fennessy, S.T., and Groenevel, J.C. (1997). A rewier of offshore trawl fisery for crustaceans on the east coast of South Africa. Fisheries management and Ecology 4, 135-147

García-Rodríguez, M. (2003). La gamba roja Aristeus antennatus (Risso, 1816) (Crustacea, Decapoda): Distribución, demografía, crecimiento, reproducción y explotación en el Golfo de alicante, Canal de Ibiza y Golfo de Vera. Tesis Doctoral. Universidad Complutense de Madrid.

García-Rodríguez, M., and Esteban, A. (1999a) On the biology and fishery of Aristeus antennatus (Risso, 1816), (Decapoda, Dendrobranchiata) in the Ibiza channel (Balearic Islands, Spain). Sci Mar 63, 27-37

García-Rodríguez, M., and Esteban, A. (1999b) A comparison between the biology and the exploitation level of two pink shrimp (Aristeus antennatus) stocks from two different areas in the Spanish Mediterranean. In von Vaupel Klein JC \& Schram FR (eds) The biodiversity crisis and Crustacea: Proceedings of the Fourth International Crustacean Congress. Balkema, Rotterdam

Holthius, L.B. (1980). FAO Species Catalogue. Shrimp and prawns of the wolrd. FAO Fisheries Synopsis 125, Vol 1.

Martínez-Baños, P., and Mas, J. (1994). Life cycle of Aristeus antennatus in the South Eastern Spain. Proceedings of International Workshop "Life cycles and fisheries of the deep-water red shrimps Aristaeomorpha foliacea and Aristeus antennatus", Mazara del Vallo, M.L. Bianchini and S. Ragonese (Eds.), N.T. R.-I.T.P.P., Special Publication. 3, 9-10.

Martínez-Baños, P. (1997) Dinámica de poblaciones de la gamba Aristeus antennatus (Crustacea, Decapoda) en las zonas de Murcia, Almería e Ibiza. Análisis global en el Mediterraneo español. $\mathrm{PhD}$ Thesis, University of Murcia

Muñoz, I., Dias, N., Salmerón, F., and Cabanelas, V. (2007). Distribution patterns of "Gamba" (Haliporoides triarthrus) in Mozambique water. 5th WIOMSA Scientific Symposium. 80p

Pérez-Farfante, I., and Kensley, B. (1997) Penaeoid and Sergestoid shrimp and prawns of the wold. Key and diagnose for the families and genera. Mém. Mus. Nat. Hist. Nat. 175, 1-233.

Ribeiro-Cascalho, A., and Arrobas, I. (1982). Aristeus antennatus (Risso, 1816): Some considerations about its biology and fisheries in Portugueses waters. ICES, C.M., 1982/K:6.

Sardá, F., and Demestre, M. (1987) Estudio biológico de la gamba Aristeus antennatus (Risso, 1816) en el Mar Catalán (N.E. España). Inv Pesq 51(Supl.1), 213-232

Sardá, F., Company, J.B., and Maynou, F. (2001) Deepsea shrimp Aristeus antennatus Risso, 1816 in the Catalan Sea: A review and perspectives. NAFO SCR Doc. 01/95, 12p

Sardá, F., D’Onghia, G., Politou, C.Y., Company, J.B., Maiorano P., and Kapiris, K. (2004). Deep-sea distribution, biological and ecological aspects of Aristeus antennatus (Risso, 1816) in the western and central Mediterranean Sea. Sci. Mar., 68 (Suppl. 3), 117-127

Sobrino, I., 1998. Biología y pesca de la gamba blanca (Parapenaeus longirostris, Lucas 1846) en el atlántico nororiental: 1-218. (Ph.D. Thesis, University of Sevilla).

Sparre, P., and Venema, S.C. (1992). Introduction to tropical fish stock assessment. Part 1. Manual. FAO Fish. Tech. Pap. no 306.1, Rev.1: 376 pp. 
